\title{
FENOMENOLOGI AGAMA: Pendekatan Fenomenologi untuk Memahami Agama ${ }^{1}$
}

\author{
Heddy Shri Ahimsa-Putra \\ Universitas Gadjah Mada Yogyakarta \\ e-mail: ahimsa_putra@yahoo.com
}

\begin{abstract}
In this article the author explains what is called 'phenomenological approach' in the study of religion. Starting from Husserl's philosophy of phenomenology, the author tracing its influences in social science through one of Husserl's students, Alfred Schutz. Based on Husserl's ideas developed by Schutz, the author presents his views how those ideas can be applied in the study of religion, and how religion can be defined phenomenologically. The author further explains some methodological ethical implications of doing phenomenological research on religion.

$* * *$

Dalam tulisan ini penulis menjelaskan apa yang disebut 'pendekatan fenomenologi' dalam kajian agama. Berangkat dari filsafat fenomenologi Husserl, penulis melacak pengaruhnya pada ilmu sosial melalui salah seorang murid Husserl, Alfred Schultz. Berdasarkan ide Husserl yang dikembangkan oleh Schultz, penulis menyajikan pandangannya bagaimana ide-ide itu dapat diterapkan dalam kajian agama, dan bagaimana agama dapat didefinisikan secara fenomenologis. Penulis selanjutnya menjelaskan beberapa implikasi etis metodologis jika melakukan kajian fenomenologis terhadap agama.
\end{abstract}

Keywords: pendekatan fenomenologi, studi agama

${ }^{1}$ Artikel ini merupakan revisi dari makalah dengan judul yang sama, yang disampaikan dalam workshop "Metodologi Penelitian Agama dalam Pendekatan Interdisipliner II," diselenggarakan oleh Lembaga Penelitian UIN Sunan Kalijaga, di Kaliurang, Yogyakarta, 1 Juni 2006.

Walisongo, Volume 20, Nomor 2, November 2012 


\section{A. Pendahuluan}

Sebagai pembuka perbincangan, akan saya paparkan terlebih dulu beberapa pandangan yang menjadi dasar uraian saya mengenai "pendekatan fenomenologi" di sini. Pertama adalah istilah "pendekatan". Istilah ini saya samakan dengan "kerangka teori", dan saya definisikan sebagai seperangkat konsep yang berhubungan satu sama lain secara logis membentuk sebuah kerangka pemikiran yang berfungsi untuk memahami, menafsirkan dan menjelaskan kenyataan atau masalah yang dihadapi. Oleh karena ada kata 'seperangkat', maka istilah "kerangka" menjadi lebih tepat, karena hal itu menyiratkan adanya sejumlah konsep yang tidak terlepas satu dari yang lain, tetapi berhubungan secara logis, masuk akal, sehingga membentuk sebuah kerangka.

Berbagai istilah sering digunakan oleh para ilmuwan untuk menyebut 'kerangka teori' ini. Diantaranya adalah: perspektif (perspective), sudut pandang (point of view), kerangka konseptual (conceptual framework), kerangka pemikiran (frame of thinking), kerangka analitis (analytical framework), aliran pemikiran (school of thought), pendekatan (approach), dan yang kini populer adalah paradigma (paradigm). Istilah-istilah ini juga akan saya gunakan secara bergantian di sini, guna menghindarkan kebosanan. Namun saya akan lebih banyak menggunakan istilah paradigma. Mengapa?

Sebagaimana dikatakan oleh Thomas Kuhn dalam bukunya The Structure of Scientific Revolutions, revolusi dalam ilmu pengetahuan pada dasarnya adalah penggantian paradigma lama oleh suatu paradigma baru yang dipandang dapat menjelaskan lebih banyak gejala atau dapat memberikan jawaban yang lebih tepat atas pertanyaan-pertanyaan baru yang dikemukakan. Walaupun kata penggantian di situ sebenarnya kurang tepat jika digunakan dalam konteks ilmu sosial budaya, namun saya setuju dengan pendapat Thomas Kuhn bahwa paradigma merupakan bagian terpenting dari ilmu pengetahuan itu sendiri, sehingga hanya perubahan dan penambahan pada paradigma itulah yang dapat dikatakan sebagai pengembangan ilmu pengetahuan. Jadi istilah pendekatan fenomenologi di sini sama maknanya dengan paradigma fenomenologi, kerangka teori atau perspektif fenomenologi.

Kedua, sebuah paradigma atau kerangka teori, mempunyai unsur-unsur yang membentuk kerangka tersebut. Dalam ilmu sosial budaya, sebuah paradigma biasanya dapat dibedakan satu sama lain atas dasar asumsi-asumsi 
atau anggapan-anggapan dasarnya tentang objek yang diteliti, masalahmasalah yang ingin dijawab atau diselesaikan, konsep-konsep, metodemetode serta teori-teori yang dihasilkannya. ${ }^{2}$ Dengan kata lain, butir-butir inilah yang dianggap merupakan unsur-unsur dasar yang ada dalam sebuah paradigma. Meskipun demikian, menurut saya, itu masih belum cukup. Masih ada elemen lain yang juga selalu ada dalam sebuah paradigma ilmu sosial budaya, namun belum tercakup di dalamnya. Selain itu unsur metode di situ masih perlu dirinci lagi.

Saya berpendapat bahwa unsur-unsur pokok sebuah paradigma ilmu sosial budaya adalah: (1) asumsi-asumsi dasar; (2) nilai-nilai; (3) masalah yang ingin diselesaikan; (4) model-model; (5) konsep-konsep; (6) metodemetode penelitian; (7) metode-metode analisis; (8) hasil-hasil analisis atau teori, dan (9) etnografi atau representasi. Oleh karena ruang yang terbatas, hanya unsur yang saya anggap penting diketahui oleh para peneliti yang akan saya uraikan, yakni (1), (3) dan (4). Untuk memahami fenomenologi dengan lebih baik saya juga akan memaparkan sedikit sejarahnya, serta konsep agama ditinjau dari perspektif fenomenologi.

\section{B. Fenomenologi: dari Filsafat ke Ilmu Sosial Budaya}

Pada awalnya fenomenologi adalah sebuah arus pemikiran dalam filsafat, dan aliran ini kini boleh dikatakan selalu dihubungkan dengan tokoh utamanya, Edmund Husserl.3 Meskipun demikian, istilah "fenomenologi" (phenomenology) sebenarnya tidak berawal dari Edmund Husserl, karena istilah ini sudah sering muncul dalam wacana filsafat semenjak tahun 1765, dan juga kadang-kadang muncul dalam karya-karya dari ahli filsafat Immanuel Kant. Dalam wacana tersebut makna istilah fenomenologi memang masih belum dirumuskan secara khusus dan eskplisit. Makna kata "fenomenologi” baru menjadi semakin jelas setelah Hegel merumuskannya. Hegel mendefinisikan fenomenologi sebagai "pengetahuan sebagaimana pengetahuan tersebut tampil atau hadir terhadap kesadaran" ("knowledge as it appears to consciousness"). Selain itu fenomenologi juga dapat diartikan se-

\footnotetext{
2 E.C.Cuff dan G.C.F. Payne, Perspectives in Sociology, (London: George Allen and Unwin, 1980), p. 3.

3 Sebagian besar tulisan di bagian ini saya ambil dari kata pengantar saya berjudul "Fenomenologi Jender di Jember" dalam buku Hamdanah, Musim Kemarau, Musim Kawin, 2002.
} 
bagai "ilmu pengetahuan tentang penggambaran apa yang dilihat oleh seseorang, apa yang dirasakan dan diketahuinya dalam immediate awareness and experience-nya. Penekanan pada proses penggambaran ini membawa kita kepada upaya mengungkapkan "phenomenal consciousness" (kesadaran fenomenal, kesadaran mengenai fenomena) melalui ilmu pengetahuan dan filsafat, menuju ke "the absolute knowledge of the absolute."

\section{Filsafat Fenomenologi: Edmund Husserl dan Pemikirannya}

Meskipun Hegel adalah tokoh yang mulai merumuskan pengertian fenomenologi dengan lebih jelas, akan tetapi hal ini rupanya tidak sangat berpengaruh terhadap Edmund Husserl, yang merupakan pelopor aliran fenomenologi. Husserl justru lebih banyak dipengaruhi oleh ahli filsafat Prancis, Rene Descartes, sebagaimana terlihat terutama pada pandangan Husserl mengenai Epoche. Husserl pada dasarnya berupaya menemukan dasar bagi sebuah filsafat yang membahas, menelaah, kenyataan. Dasar ini, menurut Husserl, hanya dapat ditemukan dalam kenyataan itu sendiri atau sesuatu itu sendiri (things in themselves). Dasar dari filsafat adalah kenyataan itu sendiri, kenyataan sebagaimana dia menampilkan dirinya, sebagaimana dia menghadirkan dirinya. Husserl melanjutkan bahwa yang dimaksudkannya dengan "sesuatu itu sendiri" (the thing itself) tidak lain adalah "kesadaran" (consciousness). Oleh karena itu, fenomenologi yang dibangun oleh Husserl dapat dikatakan sebagai ilmu pengetahuan tentang kesadaran. ${ }^{4}$

Mengapa "kesadaran"? Dalam hal ini Husserl mengikuti jejak Descartes, dengan mengawali telaahnya dari pengalaman seorang Aku yang berfikir, "the thinking ego", yang memiliki kesadaran. Bagi Husserl, kesadaran ini selalu kesadaran tentang sesuatu, "consciousness of something". Jadi ada dua aspek "kesadaran" yang saling mengisi, yakni: (1) proses sadar itu sendiri, "the process of being conscious" (the cogito), yang wujudnya bisa beberapa macam (misalnya mengingat, melihat, menilai), dan (2) yang menjadi objek dari kesadaran tersebut.

\footnotetext{
${ }^{4}$ S. Ijsseling, "Hermeneutics and Textuality: Questions Concerning Phenomenology," in Studies in Phenomenology and the Human Sciences, J.Sallis (ed.), (Atlantic Highlands, N.J.: Humanities Press., 1979), p. 5.
} 
Sebelumnya perlu diketahui bahwa "kesadaran" bukanlah sesuatu yang immanen, yang ada di dalam sesuatu, tetapi pada dasarnya bersifat intentional atau punya maksud, punya tujuan, karena kesadaran ini selalu merupakan "kesadaran tentang sesuatu", consciousness of something bukan kesadaran yang tanpa arah, yang kosong. Hal ini berarti bahwa kesadaran ini selalu diarahkan, ditujukan, kepada sesuatu. Oleh karena itu, jika dikatakan bahwa kesadaran adalah sesuatu itu sendiri, atau dasar dari semua pengetahuan, hal itu maksudnya adalah bahwa itu merupakan "kesadaran" yang mencakup semua yang muncul, yang hadir di dalam atau ada di hadapannya.

Kesadaran yang mengandung maksud tersebut selalu diarahkan kepada 'dunia kehidupan' (life world), dan dunia ini tidak lain merupakan sebuah dunia antarsubjek (intersubjective). Artinya, manusia yang berada dalam dunia tersebut saling berhubungan, sehingga kesadaran yang terbentuk di antara mereka bersifat sosial atau dimiliki bersama. Pengalaman pribadi dalam 'dunia' tersebut beserta pengalaman orang-orang lain merupakan pengalaman bersama. Proses kebersamaan ini dapat terjadi karena dalam memandang suatu gejala, entah itu benda atau peristiwa manusia selalu beranggapan bahwa gejala-gejala tersebut dialami atau bisa dialami oleh orang lain sebagaimana dia mengalaminya. Manusia selalu mengira bahwa objekobjek atau peristiwa-peristiwa tersebut bagi orang lain adalah sama halnya deng-an gejala-gejala tersebut bagi dia. Dengan kata lain dia beranggapan bahwa makna yang diberikannya pada gejala itu sama dengan makna yang diberikan oleh orang lain. Inilah yang dimaksud dengan intersubjektivitas dunia kehidupan. ${ }^{5}$

Perhatian peneliti terhadap makna suatu situasi sosial bagi pelakupelakunya mempunyai implikasi lebih jauh, yaitu pada metode yang digunakan dalam penelitian. Metode yang tepat, kata Husserl, “... follows the nature of things to be investigated and not our prejudices or conceptions". ${ }^{6}$ Hakikat makna yang ada dalam pengalaman dan tindakan manusia menyebabkan pendekatan seperti yang dilakukan pada ilmu alam dalam ilmu sosial tidak lagi mengena, karena masalahnya berada pada tingkat yang berbeda, yakni

\footnotetext{
${ }^{5}$ M. Phillipson, "Phenomenological Philosophy and Sociology" in New Directions in Sociological Theory, P. Filmer, et.al, (London: Collier MacMillan, 1972), pp. 123-126.

${ }^{6}$ Ibid., pp. 121-122.
} 
tingkat makna, yang tidak terdapat pada berbagai gejala yang diamati oleh ilmu alam. Namun, sebelum sampai pada tingkat makna itu sendiri, menurut Husserl kita perlu mengetahui terlebih dulu cara-cara yang digunakan oleh orang-orang yang kita teliti untuk memberikan arti, cap (label) yang kemudian menciptakan suatu kenyataan yang tidak mereka sangsikan lagi kebenarannya.

Mengenai phenomenon Husserl mengatakan bahwa "A phenomenon is no "substantial" unity; it has no real properties, it knows no real parts, no real changes and no casualty....To attribute a nature to phenomena, to investigate their real component parts, their causal connections - that is pure absurdity, no better than if one wanted to ask about the causal pro-perties, connections etc, of numbers. Istilah phenomenon dalam filsafat fenomenologi menunjuk pada sesuatu yang "given or indubitable in the perception or consciousness of the conscious individual", oleh karena itu fenomenologi mencakup juga usahausaha untuk mendeskripsikan, memaparkan fenomena atau gejala kesadaran, dan menunjukkan bagaimana kesadaran tersebut dibangun. ${ }^{7}$

Kata "phenomenon" sendiri berasal dari bahasa Yunani phaenesthai, yang berarti menyala, menunjukkan dirinya, muncul. Dibangun dari kata phaino, "phenomenon" berarti menerangi, menempatkan sesuatu dalam terang (brightness), menunjukkan dirinya dalam dirinya, keseluruhan apa yang ada di hadapan kita di hari yang terang. Dari sinilah muncul pandangan pokok fenomenologi, yakni "menuju sesuatu itu sendiri" (to the things themselves). Dengan kata lain menuju apa yang muncul dan memberikan dorongan (impetus) untuk adanya pengalaman dan membangkitkan pengetahuan baru. Fenomena, gejala, adalah batu-batu bangunan utama pengetahuan manusia dan merupakan dasar bagi semua pengetahuan. ${ }^{8}$

Setiap fenomena, gejala, sudah dapat menjadi titik awal untuk sebuah penelitian. Apa yang ada dalam persepsi kita mengenai sesuatu adalah kehadirannya atau merupakan penampilannya. Namun ini bukan khayalan kosong. Apa yang ada dalam persepsi tersebut merupakan awal yang sangat penting dari suatu ilmu pengetahuan yang mencari "valid determinations" dan

\footnotetext{
${ }^{7}$ Ibid.

${ }^{8}$ C. Moustakas, Phenomenological Research Methods, (London: Sage Publications, 1994), p. 26.
} 
terbuka bagi setiap orang untuk membuktikannya (to verify) (Husserl, 1931: 129). ${ }^{9}$

Ide yang sangat penting dari Husserl, yang kemudian akan sangat relevan dengan ilmu sosial budaya, adalah tentang deskripsi fenomenologis sebagai deskripsi, penggambaran dari segala sesuatu sebagaimana "adanya"; sebagaimana segala sesuatu tersebut tampil, hadir di hadapan manusia dalam cara tampilnya. Hal ini berarti bahwa fenomenologi bebas untuk menggeluti, menelaah, semua wilayah pengalaman manusia. Apakah ini tidak sama atau mirip dengan psikologi naturalistik? Tidak, menurut Husserl.

Dalam pandangan Husserl, psikologi naturalistik (naturalistic psychology), yang mengikuti cara-cara dalam ilmu-ilmu alam, seperti halnya sosiologi, telah gagal mengetahui keterbatasan-keterbatasannya, karena psikologi seperti itu telah kehilangan "sense" atau "rasa" dari gejala yang dipelajarinya. Metode-metode psikologi dipandangnya tidak tepat karena metode dan konsep yang berkembang di dalamnya telah mengabaikan fenomena "pengalaman" sebagaimana dialami oleh manusia. Oleh karena itu, menurut Husserl, metode yang benar dari sebuah disiplin ilmu pengetahuan seharusnya "follows the nature of the things to be investigated and not our prejudices and preconceptions", atau mengikuti hakikat, sifat, dari apa yang diteliti, dan tidak berdasarkan atas prasangka-prasangka atau prakonsepsi-prakonsepsi kita mengenainya (1965: 102).

Lebih dari itu, Husserl mengatakan bahwa fenomenologi tidak hanya harus menjadi "psikologi deskriptif", tetapi juga harus menjadi filsafat transendental. Artinya, dalam hal ini filsafat harus bersaing dengan ilmu pengetahuan positif, dan tidak hanya puas dengan spekulasi filosofis saja. Fenomenologi harus mencari yang transendental. Filsafat fenomenologi transendental berupaya menemukan struktur yang paling elementer, yang "we, here and now, are always departing from, and which lead and make possible our perceiving and knowing, speaking and thinking, remembering and expecting..." ${ }^{10}$ Di sinilah terletak perbedaan penting antara fenomenologi dan psikologi naturalistik, dan mengapa fenomenologi kemudian lebih dikenal sebagai aliran filsafat.

\footnotetext{
${ }^{9}$ Ibid.

${ }^{10}$ S. Ijsseling, "Hermeneutics and Textuality...., pp. 8-9.
} 
Fenomenologi sebagai logos (discourse) atau wacana tentang fenomena harus memberikan suatu deskripsi setepat mungkin tentang apa yang hadir dan ada di hadapan kesadaran. Deskripsi ini harus lengkap dan dilakukan oleh kesadaran atau oleh subjek yang sepenuhnya sadar, subjek yang menulis, yang menjelaskan tentang apa yang telah dikatakan atau ditulis. Namun deskripsi yang tepat tidak akan pernah dapat dilakukan dengan tuntas. ${ }^{11}$

Sumbangan pemikiran Husserl yang lain bagi ilmu sosial adalah pandangannya tentang natural attitude. Konsep inilah yang di kemudian hari menghubungkan filsafat fenomenologi dengan sosiologi. Lewat konsep ini Husserl mengemukakan bahwa seorang Ego yang berada dalam situasi tertentu biasanya menggunakan penalaran yang praktis, seperti dalam kehidupan sehari-hari. Ego tersebut tidak mempertanyakan lagi secara rinci apa yang ada di sekitarnya. Dia menganggap apa yang dihadapinya tidak berbeda dengan hal yang sama yang telah ditemuinya kemarin atau dulu..$^{12}$ Natural attitude ini disebut juga commonsense reality. Oleh Husserl natural attitude ini dibedakan dengan theoretical attitude dan mythical religious attitude. Dengan perbedaan ini Husserl meletakkan salah satu ide pokok yang kemudian dikembangkan oleh Alfred Schutz, dan diteruskan oleh Harold Garfinkel dalam etnometodologi. Di situ mereka menghubungkan attitude tersebut dengan bisa tidaknya proses interaksi sosial terjadi. ${ }^{13}$

Kini di Barat filsafat fenomenologi tidak lagi terlihat sebagai sebuah aliran pemikiran filosofis yang tunggal. Murid-murid Husserl telah mengembangkan ide-ide Husserl lebih lanjut, sehingga kita mengenal tokohtokoh filsafat seperti Marleau-Ponty, Martin Heidegger, Jean Paul Sartre, yang mengembangkan filsafat Fenomenologi yang dasar-dasarnya telah diletakkan oleh Husserl.

\section{Fenomenologi dalam Ilmu Sosial: Alfred Schutz Merintisnya}

Sebagaimana terlihat dalam sejarah perkembangan ilmu pengetahuan, pemikiran-pemikiran filosofis merupakan pemikiran-pemikiran yang sangat menentukan arah perkembangan ilmu pengetahuan, baik ilmu pengetahuan

11 Ibid., pp. 2-3.

12 M. Phillipson, “Phenomenological Philosophy and Sociology,” p. 127.

${ }^{13}$ Leiter, K., A Primer on Ethnomethodology, (Oxford: Oxford University Press, 1980), pp. 40-44. 
alam maupun ilmu pengetahuan kemasyarakatan dan kebudayaan. Demikian juga halnya dengan filsafat fenomenologi. Dalam perkembangannya kemudian, pemikiran-pemikiran fenomenologis yang disebarkan oleh muridmurid Husserl telah berhasil merasuk dalam disiplin sosiologi dan telah mendorong munculnya pemikiran-pemikiran dan orientasi-orientasi baru di dalamnya.

Alfred Schutz adalah salah seorang murid Husserl yang mencoba memasukkan ide-ide Husserl ke dalam sosiologi, dan apa yang dilakukannya ternyata tidak sia-sia. Schutz inilah yang kemudian merupakan matarantai penghubung filsafat fenomenologi dari Husserl dengan sosiologi. Pemikiranpemikiran Husserl yang lebih banyak aroma filosofisnya dikupas lebih lanjut oleh Schutz agar dapat diterapkan dalam ilmu sosial. ${ }^{14}$

Konsep intersubjektivitas misalnya, dikembangkan lebih jauh. Schutz berpendapat bahwa bentuk dasar intersubjektivitas ini tidak lain adalah adanya timbal-balik perspektif (reciprocity of perspective), yang mencakup dua macam bentuk idealisasi (idealization), yakni interchangability of viewpoints dan congruence of system of relevances. ${ }^{15}$ Pada idealisasi yang pertama seorang Ego beranggapan bahwa Ego dan orang lain akan mendapatkan pengalaman yang sama atas "dunia bersama" (common world) bilamana mereka saling bertukar posisi, yakni Ego berada pada posisi dia, dan dia berada pada posisi Ego. Ego berasumsi bahwa cara-cara memahami, mengalami (experiencing) dunia atau situasi yang dihadapi akan sama dalam pergantian posisi semacam ini.

Pada idealisasi kedua, masalah yang perlu dipahami adalah bagaimana si pelaku mendefinisikan situasi yang dihadapi. Situasi di sini maksudnya adalah "a particular physical and sociocultural environment in which the actor a physical, social and moral position as determined in part by his biography."16 Schutz menambahkan bahwa unsur-unsur mana yang relevan dalam suatu situasi bagi si pelaku ditentukan oleh biografi atau sejarah hidupnya serta

14 Ibid., p. 50.

15 Ibid., pp. $125-126$.

${ }^{16}$ J. Heeren, "Alfred Schutz and The Sociology of Common Sense Knowledge" in Understanding Everyday Life, J.D. Douglas (ed.), (Chicago: Aldine, 1970), pp. 47-48. 
pilihannya atas berbagai kepentingan yang menyangkut dirinya. Jadi relevansi di sini tidak lain adalah relevansi dengan masalah yang melibat si pelaku dan kepentingan-kepentingannya. Dengan demikian ki-ta dapat mengatakan bahwa yang dimaksud oleh Schutz sebagai congruence of system of relevances adalah keadaan di mana seorang Ego dan Alter yang terlibat dalam suatu interaksi berasumsi bahwa perbedaan-perbedaan yang ada dalam sistem relevansi masing-masing pihak dapat diabaikan demi tujuan yang ingin dicapai bersama. ${ }^{17}$ Melalui dua bentuk idealisasi itulah proses interaksi sosial dalam kehidupan sehari-hari dapat berlangsung dengan lancar. Di situ masing-masing pihak yang terlibat tidak lagi menyangsikan lagi bahwa hal-hal yang akan dihadapinya tidak akan berlainan dengan apa yang telah pernah dialaminya.

Selanjutnya Schutz juga mengatakan bahwa dalam proses interaksi sosial para pelaku di situ harus mendefinisikan situasi yang dihadapi, termasuk di dalamnya pelaku-pelaku yang lain. Di sini para pelaku sadar atau tidak melakukan typification atau pemberian tipe atau ciri. Dalam typification ini pelaku mengabaikan hal-hal yang unik pada suatu objek dan menempatkan objek tersebut dalam kelas yang sama dengan objek-objek lain yang memiliki ciri-ciri, unsur-unsur atau kualitas yang sama. Mengingat suatu tipe ditentukan dalam hubungannya dengan tujuan yang dimiliki maka kepentingan yang langsung inilah yang menentukan unsur-unsur mana yang menjadi kriteria penentu suatu tipe. ${ }^{18}$

Konsep typification dari Schutz inilah yang memungkinkan aliran etnosains dan antropologi kognitif dalam antropologi bertemu dengan sosiologi yang fenomenologis, sehingga etnosains dan antropologi kognitif kemudian dapat dikatakan sebagai antropologi yang fenomenologis. Dalam etnosains dan antropologi kognitif tidak digunakan konsep typifycation. Para ahli antropologi lebih banyak menggunakan isitilah classification atau categorization, yang pada dasarnya memiliki makna dan fungsi yang sama. Baik typification maupun classification atau categorization, bermakna menentukan dan memberikan ciri-ciri umum tertentu kepada sejumlah objek agar kemudian dapat dilakukan pengelompokan-pengelompokan tertentu atas objek-objek tersebut.

${ }_{17}$ M. Phillipson, “Phenomenological Philosophy and Sociology,”p. 126.

18 J. Heeren, "Alfred Schutz and the Sociology...," p. 51. 


\section{Pendekatan Fenomenologi: Asumsi Dasar dan Model}

Dengan menggunakan kerangka pemikiran di atas, fenomenologi sebagai sebuah pendekatan tentu memiliki unsur-unsur di atas. Akan tetapi dalam makalah ini tidak semua unsur tersebut akan dijelaskan. Dua unsur yang saya anggap penting saja yang akan saya paparkan di sini, yakni: asumsi dasar dan model.

\section{Beberapa Asumsi Dasar Fenomenologi}

Dari uraian mengenai pemikiran Husserl dan Schutz di atas kita dapat menemukan pokok-pokok pikiran mereka yang kemudian menjadi dasardasar bagi pendekatan fenomenologi dalam ilmu-ilmu sosial budaya. Saya mencoba untuk memaparkan asumsi-asumsi dasar fenomenologi untuk ilmuilmu sosial budaya di sini atas dasar pemikiran-pemikiran Husserl dan Schutz di atas, karena baik Husserl maupun Schutz setahu saya belum melakukannya. Husserl memang tidak pernah bermaksud membangun sebuah paradigma baru dalam ilmu sosial budaya, sedang Schutz walaupun tampaknya ingin melakukannya namun beberapa pokok pikirannya belum sempat mengkristal lebih kuat lagi, sehingga belum dapat membentuk sebuah paradigma dengan unsur-unsur yang jelas.

Dengan memaparkan pokok-pokok pikiran yang telah ada dan menambahkan beberapa hal untuk memperjelas pokok-pokok tersebut, serta menambahkan beberapa hal baru guna melengkapi unsur-unsur yang telah ada saya berharap "pendekatan fenomenologi" dengan sosok yang lebih jelas dapat kita bangun dalam ilmu sosial budaya. Beberapa butir pemikiran yang dapat menjadi landasan epistemologis pendekatan fenomenologi sosial budaya adalah sebagai berikut.

Pertama, bahwa fenomenologi memandang manusia sebagai makhluk yang memiliki kesadaran. Kesadaran ini selalu mengenai sesuatu. Tidak ada kesadaran yang tidak mengenai sesuatu, dan sesuatu itu bisa juga "kesadaran" itu sendiri. Buktinya, kita dapat merenungkan, dapat "sadar" tentang "kesadaran" kita sendiri, ketika kita melakukan "refleksi". Proses refleksi dapat dikatakan sebagai kegiatan dalam pikiran kita ketika pikiran tersebut memikirkan dirinya sendiri, memikirkan, menyadari, tentang "pikiran" itu sendiri. Kesadaran mengenai sesuatu ini adalah juga pengetahuan, sehingga kesadaran dari sisi tertentu adalah perangkat pengetahuan yang kita miliki. 
Kedua, pengetahuan pada manusia ini berawal dari interaksi atau komunikasi di antara mereka, antara individu satu dengan individu yang lain, dan sarana komunikasi yang fundamental adalah bahasa lisan. Dengan kata lain, eksistensi kesadaran manusia hanya dapat diketahui adanya lewat bahasa. Bahasa dapat dikatakan mencerminkan apa yang ada dalam kesadaran kita. Tanpa bahasa kemampuan manusia untuk mengerti dan memahami, untuk menyadari, tetap hanya akan tinggal sebagai kemampuan atau potensi, namun tidak akan dapat mewujud dan diketahui adanya.

Ketiga, oleh karena kesadaran terbangun lewat proses komunikasi, lewat interaksi sosial, maka kesadaran tersebut dengan sendirinya bersifat intersubjektif (antar subjek). Apa yang ada dalam kesadaran, dalam perangkat pengetahuan, seorang individu bisa juga ada dalam perangkat pengetahuan individu yang lain, sehingga komunikasi, interaksi sosial bisa berlangsung di antara mereka. Dengan demikian, banyak isi pengetahuan individual ini yang bersifat sosial, yang dimiliki juga orang individu-individu yang lain.

Keempat, perangkat pengetahuan atau kerangka kesadaran ini menjadi pembimbing individu dalam mewujudkan perilaku-perilaku dan tindakantindakannya. Dengan demikian perilaku dan tindakan individu tidak ditentukan oleh kondisi dan situasi "objektif" yang dihadapinya, tetapi oleh kesadarannya mengenai situasi dan kondisi tersebut. Oleh karena itu, pemahaman atas perilaku dan tindakan manusia menuntut pemahaman atas kesadaran atau pengetahuan manusia mengenai kondisi dan situasi "objektif" tersebut.

Kelima, salah satu bagian dari perangkat kesadaran tersebut adalah typification atau klasifikasi (classification), yang berupa kategori-kategori atau tipe-tipe dari unsur-unsur yang ada dalam kehidupan manusia. Kategorikategori ini digunakan manusia untuk memandang, memahami lingkungan dan kehidupannya. Melalui tirai sistem klasifikasi inilah manusia dapat menciptakan keteraturan, order, dalam kehidupannya sehari-hari, dan dapat memberikan tanggapan (response) tehadap dunianya, kehidupannya.

Adanya kesadaran atau perangkat pengetahuan yang bersifat sosial (bukan genetis), yang digunakan manusia untuk memandang dunianya inilah yang membuat manusia juga memiliki tujuan berkenaan dengan apa yang menjeadi objek kesadarannya. Tujuan, kesadaran, objek kesadaran dan kesadaran mengenai tujuan yang ada dalam diri manusia membentuk sebuah perangkat pemaknaan. Dengan perangkat ini manusia memberikan makna, 
arti pada kehidupannya, kehidupan sosialnya. Dengan perangkat pemaknaan dia menetapkan relasi-relasi tertentu antara dirinya dengan dunianya, dengan kehidupannya, dengan individu-individu yang lain. Dari sini muncul asumsi berikutnya, asumsi keenam, bahwa kehidupan manusia adalah kehidupan yang bermakna, kehidupan yang diberi makna oleh mereka yang terlibat di dalamnya.

Ketujuh, gejala sosial budaya merupakan gejala yang berbeda dengan gejala alam, karena dalam gejala sosial budaya yang terlibat adalah manusia, dan manusia memiliki kesadaran tentang apa yang mereka lakukan, tentang gejala di mana mereka terlibat; mampu memberikan makna terhadap dunia mereka. Kerangka kesadaran ini menjadi dasar atau pembimbing manusia dalam berperilaku dalam dan bertindak terhadap dunianya, sehingga pemahaman mengenai gejala sosial budaya menuntut pula pemahaman kita atas kerangka kesadaran yang digunakan untuk membangun perangkatperangkat pemaknaan tersebut.

Oleh karena itu, gejala sosial budaya tidak dapat dipelajari sebagaimana halnya kita mempelajari gejala alam. Inilah asumsi dasar yang kedelapan. Metode yang digunakan untuk mempelajari suatu gejala harus sesuai dengan "hakikat" dari gejala yang dipelajari tersebut. Kata Husserl, metode yang tepat "follows the nature of things to be investigated and not our prejudices or preconceptions." ${ }^{19}$ Ini berarti untuk dapat memahami dan menjelaskan gejalagejala sosial budaya diperlukan metode penelitian dan analisis yang berbeda dengan yang digunakan dalam ilmu-ilmu alam.

\section{2. "Model" dalam Fenomenologi}

Tidak seperti pendekatan yang lain dalam ilmu-ilmu sosial budaya, karena fenomenologi mempelajari gejala-gejala sosial budaya dengan memulai dari hal-hal yang mendasari perilaku manusia, yakni kesadaran, maka fenomenologi tidak mengajukan perumpamaan-perumpamaan atau modelmodel sebagaimana pendekatan-pendekatan yang lain. Bilamana kita mengikuti pendapat Husserl bahwa dalam mempelajari sesuatu kita sebaiknya tidak menggunakan "prejudices" atau "preconceptions" tertentu, maka model-

${ }^{19}$ M. Phillipson, “Phenomenological Philosophy and Sociology,”pp. 121-122. 
model seperti yang digunakan dalam pendekatan-pendekatan lain dalam ilmu-ilmu sosial budaya pada dasarnya adalah "preconceptions", dan itu yang ditolak oleh Husserl. Jadi, dalam fenomenologi sebenarnya tidak ada model untuk mempelajari suatu masyarakat, kebudayaan atau gejala sosial budaya tertentu, karena sejak awal fenomenologi memang tidak ditujukan untuk itu. Hal ini terkait dengan tujuan fenomenologi itu sendiri.

Fenomenologi tidak bertujuan untuk menganalisis atau menjelaskan suatu gejala. Tujuan utama fenomenologi, sebagaimana dikatakan oleh Husserl, adalah mendeskripsikan dengan sebaik-baiknya gejala yang ada di luar diri manusia sebagaimana gejala tersebut menampilkan dirinya di hadapan kesadaran manusia. Tujuan ini tidak banyak berubah ketika fenomenologi "diterjemahkan" oleh Schutz ke dalam ilmu-ilmu sosial, akan tetapi tujuan tersebut lantas diadopsi oleh ahli-ahli ilmu sosial tertentu, karena deskripsi yang dihasilkan oleh fenomenologi ternyata pada dasarnya juga merupakan salah satu bentuk dari "penjelasan" yang mereka cari.

Model yang ada dalam fenomenologi sebagian besar terdapat atau sudah terkandung dalam beberapa asumsi dasarnya, terutama asumsi yang berkenaan dengan perilaku dan perangkat kesadaran manusia. Model di sini lebih tepat disebut sebagai "gambaran", "imaji" peneliti mengenai apa yang ditelitinya, tetapi imaji bukan dalam bentuk perumpamaan atau analogi. Model yang ada di sini berkenaan dengan manusia dan perilakunya, manusia dengan jagadnya, dan sarana yang digunakan untuk membuat deskripsi mengenai gejala yang diteliti.

Fenomenologi memandang perilaku dan tindakan manusia sebagai sesuatu yang bermakna, karena manusia memberikan makna pada perilaku dan tindakan tersebut. Makna ini lahir dari kesadaran manusia akan perilaku dan tindakannya serta tujuan-tujuan yang dikenakannya pada perilaku dan tindakan tersebut. Makna-makna yang diberikan ini ada yang bersifat individual, ada pula yang sosial, kolektif, karena manusia selalu berada dalam suatu kehidupan sosial. Makna yang bersifat sosial, kolektif, artinya makna tersebut bersifat intersubjektif, dimiliki oleh orang lain juga. Makna yang kolektif ini bisa terbentuk karena manusia berinteraksi, berkomunikasi satu dengan yang lain dengan menggunakan bahasa lisan. Adanya makna kolektif yang merupakan kesadaran kolektif (collective consciousness) inilah yang melahirkan perilaku-perilaku kolektif, yang diantaranya disebut "agama". 
Dengan model tersebut, fenomena sosial budaya akan dipahami sebagai sebuah fenomena yang muncul dari suatu kesadaran kolektif. Pemahaman yang tepat, akurat, atas fenomena sosial budaya dapat diperoleh dengan memahami kesadaran kolektif yang melahirkannya. Pemahaman yang tepat dan akurat atas kesadaran kolektif tersebut hanya dapat diketahui bilamana pemahaman tersebut kemudian dideskripsikan, diwujudkan dalam bentuk uraian dengan menggunakan tulisan. Deskripsi ini merupakan wujud pemahaman fenomenologis atas gejala sosial budaya yang diteliti, yang sekaligus juga akan dapat memberikan pemahaman fenomenologis kepada mereka yang membacanya.

\section{D. "Memahami": Pengertian dan Asumsinya}

Satu konsep penting dalam fenomenologi yang perlu dijelaskan adalah "memahami". Apa yang dimaksud dengan "memahami"? Kapan kita dapat dikatakan telah memahami suatu gejala? Kata "memahami" dapat didefinisikan sebagai menunjukkan, menetapkan, menyatakan, relasi-relasi yang ada antara suatu gejala dengan gejala yang lain, namun relasi ini bukan relasi kausalitas, dan kata "memahami" lebih pas untuk digunakan dalam konteks ilmu sosial budaya, lebih tepatnya dalam konteks paradigma fenomenologis.

"Memahami" dalam konteks penelitian fenomenologis adalah mengetahui pandangan-pandangan, pengetahuan, nilai-nilai, norma, aturan yang ada dalam suatu masyarakat atau yang dianut oleh individu, dan kemudian dapat menetapkan relasinya dengan perilaku warga masyarakat, perilaku sebuah kolektivitas, atau perilaku individu tertentu. Jadi, memahami perilaku seorang individu atau suatu kolektivitas adalah mengetahui pandanganpandangan, pengetahuan, nilai-nilai dan sebagainya yang dijadikan pedoman, pembimbing, oleh suatu kolektivitas atau oleh seorang individu untuk mewujudkan perilakunya, tindakannya.

Tentu saja, pendefinisian konsep "memahami" seperti di atas berawal dari sebuah asumsi dasar bahwa perilaku manusia atau suatu kolektivitas merupakan perilaku yang berpola, yang berulang kembali. Pola-pola ini menunjukkan adanya "hukum-hukum" tertentu, yang kemudian menghasilkan pola tersebut, sebagaimana halnya yang terjadi pada gejala-gejala alam. Meskipun demikian, dalam gejala sosial budaya "hukum-hukum" tersebut tidak sama dengan dalam gejala alam. Dalam kehidupan manusia "hukum- 
hukum" tersebut terdiri dari berbagai unsur yang semuanya sedikit banyak turut menentukan pewujudan perilaku-perilaku atau tindakan-tindakan. Unsur-unsur tersebut antara lain adalah pandangan, nilai, norma dan sebagainya.

Selanjutnya, pandangan di atas didasarkan pada asumsi bahwa gejalagejala sosial budaya berbeda hakikatnya dengan gejala alam. Gejala sosial budaya diwujudkan oleh manusia, dan manusia berbeda dengan makhluk lainnya. Salah satu perbedaan utamanya adalah adanya "kesadaran". Manusia merupakan makhluk yang memiliki "kesadaran", memiliki pengetahuan mengenai apa yang dilakukannya. Kesadaran atau pengetahuan ini digunakan oleh manusia untuk menghadapi lingkungan atau situasi yang dihadapinya.

Manusia juga merupakan makhluk yang mempunyai "tujuan" dalam mewujudkan tindakannya. Tujuan ini tidak selalu hanya untuk mempertahankan hidup. Ada banyak tujuan yang melatarbelakangi perilaku dan tindakan manusia. Adanya tujuan dan pengetahuan di balik perilaku dan tindakan inilah yang kemudian melahirkan "makna" terhadap perilaku dan tindakan tersebut, serta terhadap "objek"nya. Manusia selalu memberikan makna kepada segala sesuatu dalam kehidupannya, walaupun ini tidak selalu disadarinya. Dunia manusia adalah sebuah dunia yang penuh makna (meaningful world). Inilah yang membedakannya dengan dunia binatang.

Ilmu sosial budaya yang mempelajari gejala-gejala sosial budaya mau tidak mau harus memperhatikan aspek makna ini. Kajian sosial budaya yang tidak memperhatikan dan tidak mampu mengungkapkan makna-makna yang diberikan oleh manusia terhadap kehidupannya adalah kajian yang tidak lengkap. Pengetahuan mengenai pandangan, pendapat, makna, nilai, pengetahuan yang dimiliki oleh individu atau warga suatu masyarakat merupakan salah satu syarat terpenting dalam upaya ilmu sosial budaya untuk dapat "mengerti", "memahami", gejala-gejala sosial budaya berupa berbagai pola perilaku dan tindakan manusia.

\section{E. Agama, Simbol dan Kebudayaan}

Ketika paradigma seperti di atas akan digunakan untuk meneliti fenomena keagamaan di Indonesia, maka ada lagi beberapa konsep yang perlu dijelaskan berkenaan dengannya. Dalam budaya Indonesia, istilah 'agama' 
sebenarnya memiliki makna yang berbeda dengan makna religion pada umumnya. Selain itu, agama juga berbeda dengan sistem kepercayaan. Dilihat dari sudut pandang tertentu makna 'agama' lebih luas daripada sistem kepercayaan, namun dilihat dari sudut pandang yang lain sistem kepercayaan lebih luas maknanya daripada agama. Di sini saya akan mengikuti pendapat yang pertama. Tentu saja pandangan ini tidak dapat dikatakan sebagai yang paling benar, tetapi pandangan inilah yang saat ini saya anggap masih paling cocok untuk memahami gejala sosial budaya yang disebut "agama".

\section{Manusia, Simbol dan Kebudayaan}

Berbicara mengenai agama tidak bisa lepas dari pembicaraan tentang manusia dan kebudayaan. Manusia merupakan makhluk pengemban kebudayaan, dan agama adalah bagian dari kebudayaan. Mengenai manusia ini, seorang ahli filsafat simbol, Ernst Cassirer, mendefinisikannya sebagai animal symbolicum (1945). Menurut ciri-ciri dan kondisi fisiknya, manusia mempunyai banyak persamaan dengan binatang-binatang tertentu, terutama binatang dari keluarga "kera", seperti chimpanse, gorilla, monyet, orang utan, dan sebagainya. Manusia dapat dimasukkan dalam keluarga "binatang", animal. Manusia tergolong dalam kategori mammalia (binatang menyusui), berdarah panas, dan pemakan segala (omnivore). Meskipun demikian, manusia tidaklah sama dengan binatang apapun.

Manusia memiliki kemampuan-kemampuan tertentu yang membuatnya berbeda kualitasnya dengan binatang yang manapun. Kemampuan tersebut adalah kemampuannya untuk menggunakan simbol-simbol-yang merupakan rangkaian dari tanda-tanda-, untuk menciptakan dan mengembangkan simbol-simbol, untuk menyampaikan dan memahami pesan-pesan yang disampaikan oleh manusia yang lain. Dengan kata lain manusia memiliki kemampuan untuk menggunakan simbol-simbol guna melakukan komunikasi atau untuk menyampaikan pesan-pesan.

Apa yang dimaksud dengan simbol? Simbol atau lambang saya definisikan di sini tidak sebagai sesuatu yang bermakna, tetapi sebagai segala sesuatu yang dimaknai, karena makna sebuah simbol tidaklah menempel, melekat atau ada pada simbol itu sendiri. Makna ini berasal dari luar simbol, yakni dari manusia. Manusialah makhluk yang dapat memberi makna pada sesuatu, 
yang semula bukan apa-apa. Dengan pemberian makna inilah maka apa yang semula bukan apa-apa lantas menjadi suatu simbol, suatu lambang.

Simbol paling dasar dan penting dalam kehidupan manusia adalah bahasa, yakni bunyi-bunyi yang dihasilkan oleh rongga mulut manusia. Dengan bahasa manusia dapat menyampaikan apa-apa yang ada dalam perasaan dan pikirannya kepada manusia lain, sehingga apa yang semula bersifat pribadi, individual, lantas dimiliki bersama dengan orang lain, lantas menjadi bersifat sosial atau kolektif. Atas dasar hal-hal yang bersifat kolektif inilah manusia kemudian dapat menciptakan kebudayaan dan kehidupan sosial, kehidupan bersama dengan manusia-manusia yang lain, menciptakan kegiatan-kegiatan bersama.

Atas dasar pandangan semacam itu, maka di sini kebudayaan didefinisikan sebagai perangkat simbol yang diperoleh manusia dari kehidupannya sebagai warga masyarakat dan digunakan untuk beradaptasi serta melestarikan keberadaannya sebagai makhluk hidup (spesies). Istilah "perangkat" di sini menunjukkan bahwa kebudayaan terdiri dari berbagai macam unsur, seperti misalnya pada frasa "perangkat pakaian", "perangkat gamelan". Seperangkat pakaian laki-laki misalnya terdiri dari kaos singlet, celana dalam, celana panjang dan baju. Seperangkat gamelan Jawa terdiri dari alat-alat seperti bonang, saron, kenong, gong, rebab, gender, kendang, dan sebagainya. Demikian pula halnya dengan kebudayaan. Kebudayaan juga terbangun dari berbagai macam unsur yang merupakan suatu kesatuan.

Perangkat kebudayaan di sini terdiri dari berbagai unsur yang menyatu membentuk semacam gugusan bintang-bintang, yang batas-batasnya tidak begitu jelas tetapi memiliki inti yang jelas. Kebudayaan di sini tidak dilihat sebagai sebuah sistem, sebagaimana biasa digunakan oleh penganut aliran fungsional dan fungsional-struktural. Hubungan antar unsur kebudayaan di sini juga lebih mirip seperti hubungan antara bintang satu dengan yang lain dalam sebuah gugusan bintang, daripada seperti hubungan antar unsur dalam sebuah sistem.

Hubungan antar unsur kebudayaan di sini seperti hubungan antara bumi dan rembulan. Tidak terlihat di situ keterkaitan empiris yang dapat diamati antara bumi dan bulan, namun terdapat relasi tertentu antara bumi 
dan bulannya. Bulan ternyata mempengaruhi pasang naik dan surut air laut di bumi. Gerhana bulan juga mempengaruhi perilaku makhluk di bumi. Apakah bumi juga berpengaruh terhadap bulan? Saya kurang begitu tahu, tetapi mungkin ada.

Sebagai perangkat simbol kebudayaan juga memiliki tiga wujud, yakni berupa budaya material (material culture), budaya perilaku (behavioral culture) dan budaya gagasan (ideational culture). ${ }^{20}$ Budaya material adalah simbol-simbol yang bersifat fisik, material atau bendawi, seperti misalnya mobil, sepeda motor, sepeda, pakaian, rumah dan sebagainya. Simbol-simbol fisik ini tidak harus merupakan hasil karya atau buatan manusia. Bisa saja simbol-simbol ini berupa unsur-unsur dari alam, karena manusia memberikan pemaknaan tidak hanya kepada benda-benda hasil buatannya saja, tetapi juga kepada gejala-gejala alam, sebagaimana terlihat dengan jelas pada fenomena totemisme di kalangan masyarakat yang masih sederhana.

\section{Kebudayaan, Kepercayaan dan Agama}

Dalam kaitannya dengan kebudayaan, kepercayaan merupakan salah satu bagian atau unsur kebudayaan. ${ }^{21}$ Akan tetapi, berbeda dengan unsur lainnya, kepercayaan merupakan unsur budaya yang dapat dikatakan mendasari unsur-unsur budaya yang lain. Artinya, unsur-unsur budaya lain boleh dikatakan selalu dibangun di atas seperangkat pandangan-pandangan yang diyakini kebenarannya. Pandangan-pandangan yang diyakini kebenarannya inilah yang kita sebut sebagai "kepercayaan”, "keyakinan”.

Apa sebenarnya yang dimaksud dengan "kepercayaan"? Kepercayaan dapat didefinisikan sebagai pandangan-pandangan, pendapat-pendapat, yang diyakini kebenarannya baik secara eksistensial maupun substansial, mengenai hal-hal yang empiris maupun tidak empiris, yang mendasari proses adaptasi manusia terhadap dua dunia itu (empiris dan tidak empiris). Oleh karena di sini ada sejumlah pandangan dan/atau pendapat yang seakan-akan membentuk suatu kesatuan karena tidak saling berlawanan isinya, maka pandangan-pandangan tersebut dapat dikatakan membentuk sebuah sistem.

20 Baca Koentjaraningrat, Sejarah Teori Antropologi I, (Jakarta: UI Press, 1980).

21 Ibid., h. 19. 
Oleh karena itu pula, "kepercayaan" ini lebih sering disebut sebagai sistem kepercayaan.

Unsur yang penting dalam sistem kepercayaan tersebut adalah "keyakinan akan kebenaran pandangan". Keyakinan ini berhubungan dengan "hati" manusia. Kalau unsur "pandangan" berada dalam "jagad pemikiran", maka unsur "keyakinan" berada dalam "jagad perasaan". Adanya keterkaitan antara "yang di dalam pikiran" dengan "yang di dalam perasaan" inilah membuat apa yang di dalam pikiran tersebut, pandangan-pandangan tersebut, menjadi tidak begitu mudah untuk berubah. Perubahan-perubahan pada pandangan akan dapat menimbulkan kegelisahan-kegelisahan atau perasaan tidak nyaman dalam diri pemiliknya. "Kepercayaan" sendiri bukanlah sesuatu yang berdiri sendiri. Kepercayaan ini-sebagaimana halnya "pandangan" — selalu mengenai sesuatu, baik itu mengenai eksistensinya, keberadaannya, maupun mengenai substansinya, hakikatnya, atau ciri dan sifat dari sesuatu tersebut. Dalam sistem kepercayaan kita, pandangan-pandangan ini merupakan pandangan atau pendapat yang kita akui dan yakini kebenarannya.

Selain itu, sistem kepercayaan kita juga berhubungan dengan hal-hal yang tidak empiris, atau "dunia gaib". Di sini "keyakinan akan kebenaran suatu pandangan" memainkan peran yang lebih besar lagi. Kalau berkenaan dengan dunia empiris kebenaran dari pandangan yang kita miliki dapat kita uji melalui pancaindera, tidak demikian halnya dengan pandangan-pandangan kita mengenai dunia gaib, dunia yang tidak dapat diketahui oleh pancaindera. Dunia ini hanya dapat diketahui oleh orang-orang tertentu saja, yang memiliki kelebihan kemampuan tertentu. Di sinilah "keyakinan akan kebenaran pandangan" mengenai dunia gaib tersebut menjadi tergantung pada orang lain. Orang lain ini bisa, "orang tua”, kiai, nabi, dan sebagainya.

Oleh karena suatu sistem kepercayaan mendasari kehadiran unsurunsur budaya lain, maka berkenaan dengan wujudnya sistem kepercayaan ini lebih banyak merupakan ideational culture yang berupa pengetahuan, pandangan, pendapat, dan karena itu pula bersifat abstrak. Agar dapat diketahui keberadaannya, maka ideational culture yang berupa sistem kepercayaan ini perlu diwujudkan dalam rupa yang lebih empiris, yang dapat diketahui lewat pancaindera, yakni dalam bentuk perilaku dan hasil perilaku, seperti misalnya cara memperlakukan sesuatu atau alat-alat, sarana untuk memperlakukan tersebut. 
Akan tetapi, perilaku dan peralatan ini-secara semantis-sulit untuk dikatakan sebagai bagian dari 'sistem kepercayaan'. Kata "kepercayaan" lebih mengacu pada pengetahuan yang diyakini, dipercayai kebenarannya, sehingga kurang dapat mencakup dimensi material dan behavioral dari "kepercayaan" tersebut. Di Indonesia, agama memiliki pengertian yang lebih luas daripada kepercayaan, karena kata "agama" dapat mencakup simbol-simbol yang material, behavioral maupun yang ideational. Agama di sini dapat mencakup kepercayaan-kepercayaan, yang-sebagaimana telah diuraikankurang terlihat dimensi material dan behavioral-nya.

Kebudayaan, sebagaimana telah dikatakan, merupakan perangkat simbol, sementara agama juga merupakan unsur kebudayaan. Oleh karena itu, agama pada dasarnya juga merupakan perangkat simbol-simbol. Agama tertentu dapat menjadi objek pemaknaan siapa saja, sehingga dia dapat bermakna positif maupun negatif. Dari sudut pandang tertentu agama kemudian dapat didefinisikan sebagai perangkat simbol mengenai dunia empiris dan tidak empiris-yang diyakini kebenaran eksistensial dan substansialnya-, dan menjadi sarana manusia dalam menghadapi lingkungannya atau mempertahankan hidupnya. Dunia empiris adalah dunia yang dapat kita ketahui keber-adaan dan keadaannya melalui pancaindera, sedang dunia tidak empiris adalah yang sebaliknya. Dunia ini biasa kita sebut "alam gaib", alam yang tidak kelihatan. Kebenaran eksistensial adalah keberadaan dunia tersebut, baik secara empiris maupun tidak empiris, yang dianggap benar, sedang kebenaran substansial adalah sifat-sifat, keadaan, ciri-ciri, dunia tersebut yang diyakini kebenarannya.

Kitab al-Qur'an misalnya merupakan perangkat simbolis mengenai dunia empiris dan tidak empiris. Di dalamnya terdapat paparan mengenai kehidupan manusia yang nyata, dan juga mengenai dunia yang tidak nyata (gaib), seperti malaikat, jin, setan dan sebagainya. Kebenaran eksistensial dan substansial dari fenomena yang disimbolkan ini diyakini oleh penganut agama Islam. Misalnya tentang iblis yang diyakini adanya dan yang diyakini diciptakan dari api. Simbol-simbol keagamaan al-Qur'an ini menjadi sarana bagi manusia untuk mempertahankan hidupnya, melestarikan kehidupannya dalam arti yang sebenarnya maupun kiasan.

Sebagian umat Islam yakin bahwa ayat-ayat al-Qur'an dapat digunakan untuk menyembuhkan sakit, untuk pengobatan. Penggunaan ayat al-Qur'an 
untuk penyembuhan sakit fisik merupakan contoh konkret dari pemanfaatan simbol keagamaan untuk mempertahankan hidup. Selain itu, ayat-ayat tersebut juga diyakini dapat menyembuhkan sakit "hati" seperti, kesedihan, ketakutan, kekhawatiran, dan sebagainya. Ketika ayat-ayat al-Qur'an dibaca dengan maksud untuk menghapus rasa takut, sedih, khawatir, dan sebagainya, maka ketika itu simbol tersebut dimanfaatkan untuk melestarikan kehidupan, karena ketika rasa takut, sedih, telah hilang manusia dapat kemudian bekerja kembali untuk melanjutkan kehidupannya.

Kitab al-Qur'an merupakan salah satu perangkat simbol dalam agama Islam, bahkan perangkat simbol yang terpenting. Perangkat simbol material yang lain misalnya masjid untuk shalat, air untuk berwudhu, pakaian untuk menutup aurat dan beribadah, kitab-kitab hadits, kitab-kitab para ulama. Makanan untuk berbuka puasa, dan sebagainya. Perangkat simbol behavioral misalnya adzan, iqamat, bersedekah, berpuasa, menjalankan shalat, menyembelih binatang kurban, dan sebagainya. Perangkat simbol ideational misalnya konsep tauhid, iman, aqidah, takwa, dan sebagainya. Agama Islam merupakan kumpulan dari simbol-simbol ini semua.

Dikatakan sebagai simbol karena unsur-unsur itu semua dapat dimaknai oleh siapapun. Pemaknaan ini dapat berbeda-beda. Perbedaan makna yang diberikan tidak hanya ada pada tataran kelompok atau golongan, tetapi bahkan juga pada tataran individual. Tidak ada individu yang sama persis pemaknaannya satu dengan yang lain, walaupun itu berkenaan dengan satu simbol saja. Pemaknaan yang diberikan terhadap sebuah ayat misalnya, tidak akan bisa persis sama antara individu satu dengan yang lain. Walaupun demikian, di antara pemaknaan yang berbeda-beda ini juga terdapat kesamaan-kesamaan tertentu pada beberapa bagiannya, sehingga sebuah pemaknaan yang bersifat kolektif atas sebuah simbol dimungkinkan adanya.

\section{Agama dan Kepercayaan: Individual dan Kolektif}

Agama mempunyai dua dimensi, yakni: dimensi kolektif dan individual. Artinya, ada pandangan-pandangan yang kebenarannya diterima secara kolektif, diyakini oleh sejumlah orang, oleh sekelompok orang, ada pula yang hanya diikuti oleh satu orang saja. Pada awalnya agama ini bersifat individual apalagi jika ini mengenai hal-hal yang tidak empiris atau dunia gaib, tetapi melalui proses komunikasi, pandangan-pandangan yang semula hanya di- 
yakini oleh satu orang ini kemudian diterima oleh banyak orang, dan menjadi milik suatu kolektivitas atau kumpulan individu.

Sebagaimana pengetahuan dan pandangan-pandangan lain dalam suatu kebudayaan unsur-unsur dalam suatu agama berawal dari pengalaman individual. Bahkan pandangan-pandangan yang diterima dari orang lain tidak selalu diterima begitu saja oleh orang lain. Seorang individu biasanya memproses, memikirkan kembali, meninjau kembali, mempertanyakan kembali berbagai hal yang diterimanya dari orang lain ketika dia telah memiliki pengetahuan yang semakin banyak mengenai berbagai hal. Pada masa kanakkanak seorang individu biasanya memang lebih banyak bersifat pasif, menerima begitu saja apa yang diberitahukan kepadanya. Namun, ketika dia bertambah dewasa dan bertambah pengetahuannya mengenai hal-hal yang ada di sekitarnya, yang ada dalam dunianya, dia mulai bersikap kritis, bahkan dia berusaha untuk membangun sendiri pandangan-pandangan baru.

Berbagai pengalaman dan keterangan yang dia peroleh dari orang lain dia pikirkan kembali, dia pertanyakan kebenarannya, sampai dia tiba pada pendapat atau pandangan yang diyakininya sebagai hal yang benar. Pandangan yang benar inilah yang kemudian dijadikan dasar bagi pewujudan perilaku dan tindakannya sehari-hari. Selanjutnya pandangan-pandangan semacam ini bertambah banyak dari hari ke hari, seiring dengan berbagai pengalaman baru yang diperoleh, yang kemudian menjadi seperangkat pandangan, yang biasa kita sebut sebagai "pandangan hidup", yang tidak lain adalah pendapat-pendapat mengenai berbagai hal yang ada dalam kehidupan manusia yang dijadikan pedoman untuk mewujudkan perilaku dan tindakan. Pandangan hidup individual yang merupakan hasil dari berbagai pengalaman yang diperoleh seorang individu ini merupakan agama yang bersifat individual. Pandangan hidup ini tidak dimiliki oleh orang lain, karena banyak pengalaman-pengalaman yang sangat pribadi yang kemudian membentuk keseluruhan pandangan hidup tersebut.

Sebagian dari pandangan-pandangan tersebut kemudian ada yang disampaikan kepada orang lain, dan kemudian diterima kebenarannya oleh orang lain juga. Di sini kepercayaan tersebut menjadi milik kolektif, dan ini akan menjadi dasar bagi munculnya pola-pola perilaku kolektif. Ketika kegiatan kolektif yang didasarkan pada seperangkat kepercayaan tertentu itu muncul, sistem kepercayaan tersebut pada dasarnya telah menjadi semakin 
kuat, karena dia mulai mempunyai akar sosial, akar yang masuk ke dalam kehidupan masyarakat secara langsung.

Ketika sebuah kepercayaan atau agama telah berada pada tataran kolektif, telah diikuti banyak orang, maka perubahannya akan menjadi lebih sulit, karena perubahan tersebut akan menuntut persetujuan atau kesepakatan kolektif juga. Sebelum suatu pandangan sepakat untuk diganti atau diubah, akan banyak individu yang menganut pandangan tersebut mem-pertanyakan manfaat dan kebenaran dari usaha perubahan itu sendiri. Di sinilah terjadi proses seleksi yang ketat pada tataran kepercayaan, jika perubahan-perubahan akan dilakukan. Kenyataan semacam ini menyiratkan bahwa agama suatu masyarakat dapat menjadi wahana yang penting dalam proses perubahan, karena di situ sistem kepercayaan dapat menjadi semacam penyaring, pengontrol, proses perubahan yang tengah atau akan berjalan.

\section{F. Agama: Perspektif Fenomenologi}

Dalam perspektif fenomenologi agama tentu berbeda definisinya dengan yang telah dikemukakan di atas. Agama dalam perspektif fenomenologi pertama-tama harus didefinisikan sejajar dengan pandangan Husserl mengenai phenomenon, yakni sebagai suatu bentuk kesadaran (consciousness). Di sini saya mencoba untuk mendefinisikan "agama" dari sudut pandang fenomenologi sejauh yang dapat saya pahami, karena setahu saya belum hingga saat ini belum ada upaya untuk mendefinisikan agama lewat pendekatan ini. Oleh karena ini merupakan sebuah upaya awal maka definisi ini sebaiknya tidak diterima sebagai satu-satunya kebenaran. Sebaliknya, definisi ini harus dipahami dengan sikap kritis.

\section{Agama: Definisi Fenomenologis}

Secara fenomenologis agama dapat didefinisikan sebagai sebuah kesadaran mengenai (a) adanya dunia yang berlawanan-gaib dan empirisdan (b) bagaimana manusia sebagai bagian dunia empiris (c) dapat menjalin hubungan simbolik dengan dunia gaib tersebut.

Definisi di atas menekankan aspek kesadaran dalam fenomena agama karena aspek kesadaran inilah yang ditekankan oleh Husserl. Sebagai suatu kesadaran, agama bisa bersifat individual, bisa pula sosial atau kolektif. Ketika kajian agama yang dilakukan lebih mengarah pada kesadaran yang individual 
sifatnya, maka kajian tersebut akan dapat bertemu dengan kajian psikologi agama, sedang ketika kajian yang dilakukan lebih mengarah pada aspek sosialnya, maka kajian tersebut akan merupakan kajian sosiologi agama atau antropologi agama, dengan perspektif fenomenologi.

Sebagai sebuah kesadaran individual, maka dengan sendirinya "agama" tersebut akan merupakan suatu kesadaran yang sangat pribadi, yang tidak dimiliki oleh individu-individu yang lain. Deskripsi fenomenologis agama yang bersifat individual ini akan menekankan kesadaran-kesadaran, pengetahuan-pengetahuan, pandangan-pandangan individual, yang khas sifatnya, yang kemudian mendorong munculnya perilaku-perilaku khas pula, yang individual.

Sebagai sebuah kesadaran kolektif, maka "agama" akan merupakan sebuah kesadaran yang dimiliki bersama, sebuah kesadaran yang unsurunsurnya dimiliki oleh banyak individu. Deskripsi fenomenologis agama pada dimensi kolektifnya ini akan menekankan pada kesadaran-kesadaran, pengetahuan-pengetahuan, pandangan-pandangan yang bersifat kolektif, intersubjektif, yang mendorong munculnya perilaku-perilaku kolektif pula, yang menunjukkan adanya suatu 'umat', jamaah, dari agama tersebut.

\section{Kesadaran tentang "Yang Gaib" dan "Yang Nyata/Empiris"}

Kesadaran mengenai dunia yang gaib dan dunia yang empiris tersebut adalah kesadaran mengenai ciri-ciri dua dunia tersebut, sifat-sifat dunia tersebut dengan berbagai subjek atau "makhluk" yang mendiaminya. Deskripsi fenomenologis mengenai alam gaib dan alam empiris bisa juga difokuskan pada deskripsi kesadaran yang individual atau yang kolektif.

Deskripsi bisa memusatkan perhatian pada unsur-unsur, sifat-sifat dan keadaan dunia gaib sebagaimana diketahui, disadari, dan diyakini oleh seorang individu atau oleh suatu jamaah. Misalnya deskripsi mengenai dunia gaib yang bernama "surga" dan "neraka", dengan segala ciri dan keadaannya. Deskripsi juga dapat memusatkan subjek-subjek yang ada dalam dunia gaib tersebut, seperti misalnya "malaikat", "bidadari", "iblis", "jin" dan sebagainya dengan segala ciri, sifat dan perilaku mereka. Pada masyarakat-masyarakat yang masih sederhana, yang belum mengenal agama-agama be-sar di dunia, deskripsi dunia gaib ini bisa mengenai keadaan dunia tempat tinggal nenekmoyang mereka yang telah meninggal, mengenai kehidupan mereka, 
mengenai tokoh-tokoh yang mendiami dan berkuasa di dunia situ, dan sebagainya.

Dalam kaitannya dengan dunia empiris, deskripsi mengenai dunia ini secara fenomenologis dan sekaligus berdimensi agamawi akan selalu dikaitkan dengan dunia gaib, sebab deskripsi fenomenologis mengenai dunia empiris yang tidak berkaitan dengan dunia gaib akan membuat deskripsi tersebut kehilangan nuansa "keagamaannya". Deskripsi ini juga dapat memfokus pada kesadaran yang bersifat individual, dapat pula memfokus pada kesadaran yang bersifat kolektif.

Bagian-bagian dari dunia empiris yang bersifat "keagamaan" adalah simbol-simbol di dunia empiris yang berhubungan dekat atau langsung dengan dunia gaib. Simbol-simbol ini bisa berupa peralatan, manusia (tokoh-tokoh keagamaan, pelaku-pelaku kegiatan keagamaan), perilaku manusia (ritual, ibadah), atau ide-ide, pesan-pesan yang ingin disampaikan ke dunia gaib (doa, mantera). Kajian fenomenologi gejala keagamaan akan berusaha mendeskripsikan kesadaran pelaku keagamaan mengenai simbol-simbol tersebut.

\section{Kesadaran tentang "Komunikasi Dunia Gaib dan Dunia Nyata/Empiris"}

Dalam agama, eksistensi dunia gaib tidak bisa dilepaskan dari dunia manusia yang empiris. Demikian pula sebaliknya. Selanjutnya, dua dunia tersebut hanya memperoleh maknanya ketika ditempatkan dalam relasi dengan manusia, karena manusialah makhluk yang dapat memberikan makna-makna. Manusia merupakan unsur utama penghubung dua dunia yang berlawanan, sekaligus pemberi makna kepada dua dunia tersebut serta hubungan di antara keduanya.

Untuk menjalankan peran sebagai penghubung tersebut, manusia memerlukan perangkat komunikasi yang semuanya merupakan simbol-simbol baik material, behavioral maupun ideational. Simbol-simbol untuk melakukan komunikasi dengan dunia gaib inilah yang biasa disebut sebagai simbol-simbol "keagamaan". Kajian fenomenologis di sini akan berupaya mengungkap dan mendeskripsikan kesadaran pemeluk agama mengenai simbol-simbol "keagamaan" tersebut, simbol-simbol yang digunakan oleh manusia yang berada dalam dunia empiris untuk berkomunikasi dengan dunia gaib, untuk "menyapa" tokoh-tokoh, pelaku-pelaku dalam dunia gaib. 
Komunikasi yang berusaha dibangun oleh manusia dengan dunia gaib pada inti-nya merupakan sebuah upaya untuk menyampaikan pesan-pesan kepada dunia tersebut. Pesan-pesan tertentu seringkali akan disampaikan melalui simbol-simbol tertentu pula, dan dalam waktu dan di tempat yang tertentu. Deskripsi fenomenologis atas fenomena keagamaan juga akan menampilkan kesadaran-kesadaran pelaku mengenai pesan-pesan yang ingin disampaikan, serta waktu dan tempat untuk menyampaikan pesan-pesan tersebut.

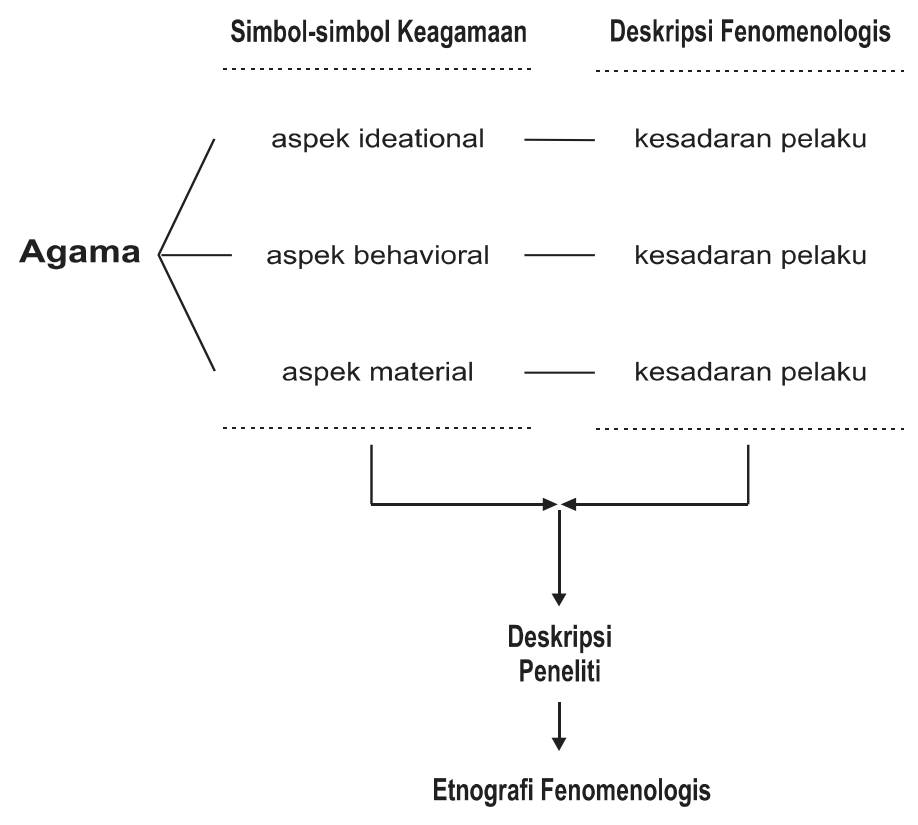

Gambar 1.

Gejala Keagamaan dalam Deskripsi Fenomenologis

Berbagai keterangan yang diperoleh dari wawancara dengan para informan mengenai hal-hal di atas kemudian harus ditulis sedemikian rupa sehingga kesadaran kolektif masyarakat yang diteliti mengenai apa yang mereka sebut "agama" dapat tampil dengan jelas dan mudah dimengerti oleh pembaca. Deskripsi agama secara fenomenologis ini dengan sendirinya sangat perlu mempertahankan istilah-istilah lokal, atau istilah-istilah yang 
digunakan oleh masyarakat setempat untuk menyebut hal-hal yang termasuk dalam 'agama' mereka.

Di sini peneliti harus selalu waspada untuk tidak menggunakan pengetahuannya sendiri untuk memahami berbagai fenomena keagamaan yang ditemuinya dalam penelitian. Peneliti harus selalu sadar untuk tidak menggunakan anggapan-anggapannya, definisi-definisinya, atau konsep-konsepnya sendiri. Kewaspadaan semacam inilah yang akan dapat menghasilkan sebuah etnografi fenomenologis yang maksimal dari 'agama' atau 'kepercayaan' suatu masyarakat (lihat skema pada gambar 1 di atas).

\section{G. Prinsip Etis-Metodologis Penelitian Fenomenologi Agama}

Setiap pendekatan dalam ilmu sosial budaya pada dasarnya menyimpan juga di dalamnya sejumlah prinsip etis-metodologis yang perlu diperhatikan oleh mereka yang menggunakan pendekatan tersebut dalam penelitiannya, karena prinsip etis-metodologis ini terkait erat secara logis dengan beberapa asumsi dasar yang ada dalam pendekatan tersebut. Demikian pula halnya dengan pendekatan fenomenologis.

Beberapa prinsip etis-metodologis yang perlu diperhatikan dalam menerapkan pendekatan fenomenologis untuk penelitian agama antara lain adalah:

1. Tidak menggunakan kerangka pemikiran tertentu untuk menentukan atau menilai kebenaran pandangan "tineliti" (subjek yang diteliti), karena tugas peneliti bukanlah untuk menilai atau menentukan kebenaran pandangan keagamaan yang diteliti, tetapi mendeskripsikan dengan sebaik-baiknya pandangan keagamaan tersebut lewat perspektif penganutnya. Prinsip ini mungkin agak sulit untuk diterapkan oleh mereka yang belum biasa melakukan penelitian dengan paradigma fenomenologi. Apalagi oleh mereka yang biasanya melakukan penelitian dengan paradigma "normatif", yakni berangkat dari norma-norma keagamaan tertentu yang diyakini kebenarannya untuk menentukan apakah fenomena sosial budaya yang dihadapi "sesuai" dengan normanorma tersebut atau tidak. Meskipun demikian, prinsip ini dapat dijaga selama penelitian dengan cara selalu menyadari posisi peneliti sebagai "pelajar" (Spradley, 19), yang berkeinginan untuk mengetahui pandangan- 
pandangan masyarakat yang diteliti berkenaan dengan perilaku dan pola kegiatan keagamaan yang mereka lakukan.

2. Pandangan-pandangan keagamaan yang berhasil diperoleh juga tidak perlu ditentukan mana yang paling benar, karena dari sudut pandang Fenomenologi, setiap "kesadaran" adalah "benar", sehingga setiap pandangan keagamaan sama posisinya, sama kedudukannya, dan sama berhaknya untuk ditampilkan dalam sebuah etnografi. Banyak peneliti sosial yang melakukan penelitian dengan tujuan untuk menemukan "kebenaran" suatu fenomena sosial di lapangan. Oleh karena "kebenaran" ini dianggap hanya ada satu-karena kebenaran dianggap bersifat tunggal一, maka ketika berhadap-an dengan kenyataan bahwa para informan tidak selalu memiliki pandangan yang sama mengenai fenomena tertentu, peneliti merasa kebingungan, dan berusaha-jika tidak memaksakan diri- untuk memperoleh "satu" versi yang biasa dianggap paling benar. Anggapan semacam ini kurang tepat dalam konteks penelitian yang fenomenolo-gis, karena setiap kelompok dalam sebuah komunitas bisa saja memiliki pandangan yang berbeda-beda mengenai suatu fenomena sosial budaya dalam komunitas tersebut. Dalam penelitian semacam ini tujuan utama bukanlah menemukan sebuah "versi" yang paling benar tentang suatu fenomena, tetapi mengungkapkan berbagai pola pandangan atau "versi" yang ada dalam masyarakat. Jika peneliti hanya mencari sebuah "versi" - yang dianggap paling benarhal itu berarti bahwa peneliti akan "menyensor" datanya, dan meniadakan versi-versi yang lain. Akibatnya etnografi yang ditampilkan tidak lagi dapat mencerminkan "realitas yang sebenarnya".

3. Dalam berhadapan dengan tineliti posisi peneliti adalah sebagai "murid" yang ingin memahami pandangan-pandangan keagamaan seorang individu atau suatu komunitas tertentu, yang kemudian bermaksud mendeskripsikan pandangan-pandangan tersebut dengan sebaik-baiknya, artinya secocok mungkin dengan apa yang dimaksud oleh tineliti. Menempatkan diri sebagai seorang "murid" dalam penelitian memang tidak selalu mudah dilakukan. Apalagi jika dalam kehidupan sehari-hari peneliti adalah seorang guru, dosen di perguruan tinggi, tokoh masyarakat atau tokoh keagamaan. Yang paling sulit dilakukan oleh peneliti adalah apabila masyarakat atau komunitas yang ditelitinya memiliki 
pandangan atau keyakinan keagamaan yang tidak sangat berbeda dengan pandangan peneliti. Dalam situasi seperti ini biasanya-tanpa disadari-peneliti akan terjebak untuk menjadi "guru", bukan "murid". Dia akan menjelaskan pandangan-pandangannya yang dianggapnya "benar", dan tanpa sadar menganggap pandangan masyarakat setempat "salah". Tanpa disadari, dalam situasi seperti itu dia sebenarnya tidak lagi menjadi peneliti yang sedang mencari data, tetapi telah berubah menjadi seo-rang "ustadz". Hal semacam ini sama sekali tentu saja tidak akan menguntungkan penelitiannya sama sekali, karena pada akhirnya dia tidak akan dapat mengumpulkan data "sebagaimana adanya". Lebih buruk lagi dia tidak akan berhasil menggali pandangan dan keyakinan para informannya, karena pikirannya telah tertutup oleh "ideologi" keagamaannya sendiri, yang dianggapnya paling benar.

4. Peneliti harus berusaha untuk tidak mengemukakan pendapat-pendapatnya, yang mungkin akan berlawanan dengan pandangan-pandangan tineliti, karena hal itu dapat mengganggu hubungan antara peneliti dengan tineliti, yang kemudian akan berpengaruh terhadap kualitas data yang berhasil dikumpulkan. Dalam penelitian fenomenologis ini seorang peneliti harus selalu sadar bahwa tujuan utamanya adalah mengungkapkan pandangan, keyakinan atau kesadaran kolektif masyarakat berkenaan dengan fenomena keagamaan tertentu. Untuk mencapai tujuan tersebut peneliti harus lebih banyak bertanya pada informan, daripada menjelaskan atau menjawab pertanyaan mereka. Oleh karena itu, peneliti harus betul-betul siap dengan berbagai pertanyaan untuk para informan. Tentu saja dalam hal ini peneliti juga tetap harus memperhatikan apakah informan telah bosan, kesal, atau tetap bersema-ngat menjawab pertanyaan-pertanyaannya. Ini untuk menjaga hubungan pribadi antara peneliti dengan tineliti. Terlalu agresif dalam bertanya bisa menimbulkan kejengkelan pada pihak tineliti, demikian juga kalau peneliti terlalu banyak memberikan penjelasan atau memberikan "ceramah" kepada tineliti. Di sini peneliti dituntut untuk mampu menjaga wawancara yang menyenangkan, yaitu yang seimbang antara menggali keterangan yang lengkap dari informan dengan memberikan keterangan secukupnya kepada dia, agar tidak menimbulkan kesan pelit berbagi pengetahuan dan menggurui informan. 


\section{H. Kesimpulan}

Dalam tulisan ini saya telah mencoba untuk menjelaskan secara singkat pendekatan fenomenologi yang berkembang dalam ilmu sosial budaya, karena adanya pengaruh dari filsafat fenomenologi yang dikembangkan oleh Edmund Husserl, dan bagaimana pendekatan tersebut dapat digunakan untuk memahami fenomena keagamaan.

Berbeda dengan kebanyakan penelitian ilmu sosial budaya yang tujuan utamanya adalah menjelaskan gejala-gejala sosial budaya, penelitian Fenomenologis ditujukan terutama untuk mendeskripsikan dengan sebaik-baiknya gejala sosial budaya menurut sudut pandang subjek yang diteliti. Asumsinya adalah bahwa manusia merupakan makhluk yang memiliki kesadaran, memiliki pengetahuan, atas apa yang dilakukannya, serta memiliki tujuantujuan berkenaan dengan perilaku atau tindakannya. Kesadaran inilah yang membuat gejala sosial budaya bermakna tidak hanya bagi peneliti tetapi juga bagi pelakunya, dan makna-makna yang perlu ditampilkan, pertama-tama, adalah makna dari para pelaku tersebut, bukan makna yang diberikan oleh peneliti.

Sehubungan dengan gejala keagamaan, jika pendekatan fenomenologi digunakan untuk memahami gejala tersebut, perhatian utama peneliti akan diarahkan pada kesadaran, pada pengetahuan subjek yang diteliti mengenai perilaku dan tindakan keagamaan yang mereka lakukan. Kesadaran inilah yang kemudian akan dipaparkan dengan sebaik-baiknya, selengkap-lengkapnya, secocok mungkin dengan apa yang dimaksud oleh tineliti.

Agar tujuan tersebut dapat dicapai maka peneliti perlu menempatkan dirinya sebagai seorang "murid" yang ingin mengetahui sebaik-baiknya pengetahuan yang dimiliki oleh para tineliti mengenai gejala keagamaan yang mereka terlibat di dalamnya. Dalam posisi semacam ini, tidak pada tempatnya kalau peneliti kemudian berusaha menentukan "kebenaran" ataupun "kekeliruan" dari kesadaran atau pengetahuan yang dimiliki para tineliti mengenai gejala keagamaan tersebut. Dengan kata lain, "relativisme agama" merupakan sebuah prinsip penelitian yang perlu diikuti dalam penelitian atas gejala keagamaan dengan menggunakan pendekatan fenomenologi, dan ini bukanlah sesuatu yang mudah dilakukan terutama oleh mereka yang tanpa sadar sudah begitu terbiasa menggunakan pandangan-pandangan keagamaan dogmatis yang self-righteous sebagai kerangka pemikiran untuk me- 
mandang, memahami dan menjelaskan berbagai macam peristiwa dalam kehidupan sehari-hari.[w] 


\section{BIBLIOGRAFI}

Ahimsa-Putra, H.S., "Etnosains dan Etnometodologi: Sebuah Perbandingan," Masyarakat Indonesia, Th. XII, No. 2,1985, h. 103-134.

. "Fenomenologi Gender di Jember," dalam Hamdanah, Musim Kawin di Musim Kemarau, Yogyakarta: Bigraf, 2005.

Cuff, E.C. dan G.C.F. Payne, Perspectives in Sociology, London: George Allen and Unwin, 1980.

Filmer, P., "On Harold Garfinkel's Ethnomethodology" dalam New Directions in Sociological Theory, P. Filmer et al (eds.), London: Collier MacMillan, 1972.

Geertz, C., The Interpretations of Cultures, New York: Basic Books, 1973.

Heeren, J., "Alfred Schutz and the Sociology of Common Sense Knowledge" dalam Understanding Everyday Life, J.D. Douglas (ed.), Chicago: Aldine, 1970.

Ijsseling, S., "Hermeneutics and Textuality: Questions Concerning Phenomenology" dalam Studies in Phenomenology and the Human Sciences, J. Sallis (ed.). Atlantic Highlands, N.J.: Humanities Press, 1979.

Jackson, M., "Introduction: Phenomenology, Radical Empiricism, and Anthropological Critique" dalam New Directions in Phenomenological Anthropology, M. Jackson (ed.), Bloomington: Indiana University Press, 1996.

Koentjaraningrat, Sejarah Teori Antropologi, Jil. I, Jakarta: UI Press, 1980.

Laughlin, C.D., "Phenomenological Anthropology" in Encyclopedia of Cultural Anthropology, Vol. 3, 1996, pp. 924-926.

Leiter, K, A Primer on Ethnomethodology, Oxford: Oxford University Press, 1980.

Moran, D., Introduction to Phenomenology, London: Routledge, 2000.

Moustakas, C., Phenomenological Research Methods, London: SAGE Publications, 1994.

Phillipson, M., "Phenomenological Philosophy and Sociology" in New Directions in Sociological Theory, P. Filmer et.al (eds.), London: Collier MacMillan, 1972. 
Silverman, D., "Introductory Comments"; "Methodology and Meaning"; "Some Neglected Questions about Social Reality" dalam New Directions in Sociological Theory, P. Filmer, et al (eds.), London: Collier MacMillan, 1972.

Psathas, G., "Ethnomethods and Phenomenology", Social Research, Vol. 35, 1968, pp. 500-520.

Van Baal, J., Symbols for Communication, Assen: Van Gorcum, 1971. 